\title{
Communication Climate as Predictor of Role Conflict among Subordinate Staff of Salman bin Abdulaziz University
}

\author{
Nasser S. Al-Kahtani ${ }^{1} \&$ Zafrul Allam ${ }^{1}$ \\ ${ }^{1}$ Department of HRM, College of Business Administration, Salman bin Abdulaziz University, Kingdom of \\ Saudi Arabia \\ Correspondence: Zafrul Allam, Department of HRM, College of Business Administration, Salman bin Abdulaziz \\ University, Kingdom of Saudi Arabia. E-mail: zafrulallam@rediffmail.com
}

\author{
Received: December 16, 2014 Accepted: January 8, 2015 Online Published: April 30, 2015 \\ doi:10.5539/ass.v11n12p248 \\ URL: http://dx.doi.org/10.5539/ass.v11n12p248
}

\begin{abstract}
In the fast pace of world communication process, role conflict among employees becomes core concern of the higher officials. Thereby, the present study was an attempt to explore the contribution and relationship of supportive and defensive communication climate on role conflict among subordinate staff of Salman bin Abdulaziz University, Kingdom of Saudi Arabia. The sample included in the study is 368 subordinate staff working in various departments of the university. Communication climate inventory developed by Gibb's (1961) and role conflict scale by Rizzo, et al., (1970) was used to determine the experiences of subordinate staff. Pearson's product-moment correlation and step wise multiple regression analysis were used. The findings of the present investigation revealed that (i) defensive communication climate and their facets were positively related with role conflict, (ii) total defensive communication climate and their two facets (superiority and control) were emerged most dominant predictors of role conflict, (iii) supportive communication climate and their facets were showed positive significant relationship with role conflict, and (iv) empathy emerged as one of the most important predictor of role conflict. The present investigation tempted to provide certain implication and suggestion to add value in the contemporary areas of knowledge.
\end{abstract}

Keywords: communication, climate, supportive \& defensive climate, role conflict

\section{Introduction}

In the fast pace of present scenario of the technological era, it is not possible to operate/run the business in an effective manner without communication. Therefore, all types of sectors in the business world conducting business and making profits with the help of internal and external communication to deals with different stakeholders. Moreover, it has been seen that organizational communication couldn't be imagined without conflict and role conflict related to the workforce comes across most commonly in the workplace. Researchers has pointed that extreme role conflict is harmful as well as low level conflict is not good for better output.

The easiest way to define "communication is transfer of information from sender to receiver, but implying that the receiver must understands the message in the same way as sender intent to say". However, Richmond et al, (2005) defined "organizational communication is the process by which individuals stimulate meaning in the minds of other individuals by means of verbal or nonverbal messages". As Lesikar et al., (1999) pointed out that "communication is the ingredient which makes organization possible". Moreover, it is necessary to understand communication climate with regard to general feeling and manifested, freedom of expression, openness and sincerity, warmth and sense of acceptance of others, interrelations, the level of cooperation within the organization and conflict resolution because it is considered as a key determinants of organizational effectiveness. As we know that during the process of communication, the sender reveals about the feelings of his or her attitude, interest, value and manifest to influence others. Adler, et al., (2009) said that "communication climate is a term that refers to the emotional tone of a relationship". The concept can be elaborated in terms of the mode people feel about each other as they carry out their daily activities. Hence, climates can be found in families, friendships and all other types of relationships that have their own societal manner. In early sixties Gibb (1961) identified six characteristics of "supportive communication climate" and six characteristics of "defensive communication climate". He characterized the supportive climate as an environment in which the work is done within the frame of provisionalism, empathy, equality, spontaneity, problem orientation and description and 
defensive climate as an environment which comes with evaluation, control, strategy, neutrality, superiority and certainty.

It seems that when the responsibilities of the individual are not rightly or properly defined, role conflict will emerge. Conflicts can be seen in the form of disagreement which indicates issues related to task and interpersonal and emotional issues which lead to conflict. It has been noticed in the organization that conflict sometimes considered as constructive at optimum level or normal range but beyond such point conflict may become dangerous. It can be positive when it defeats organizational sluggishness and makes to development of the organization. Role conflict is defined as "the degree of incongruity or incompatibility of expectations associated with the role". Various researchers defined role conflict in a different ways. Kahn et al., (1964) has been explained role conflict as "the simultaneous occurrence of two or more role pressures so that the compliance with one makes it more difficult to comply with the other". Katz and Kahn (1966) de fined role conflict as "the simultaneous occurrence of two or more sets of pressure such that the compliance with one would make the other more difficult". Rizzo et al., (1970) role conflict can be defined as "The contradicting roles carried out by an individual in an organization". Glissmeyer et al., (1985) explained role conflict as "the level to which a person experiences pressures within one role that is incompatible with pressures that take place within another role". Cooper et al. (2001) is defined role conflict as "reflects incompatible demands on the person (either within a single role or between multiple roles occupied by the individual) which can induce negative emotional reactions due to the perceived inability to be effective on the job". Rahim (2002) said that conflict can be conceptualized as "an interactive process manifested in disagreement, incompatibility, or dissonance between or within entities of social such as organization, group, individual etc". Jones (2007) has been defined role conflict as "the person may be caught between in the crossfire between two supervisors or the needs of two function group". Onyemah (2008) defined role conflict as "a feeling of being torn in multiple directions, unable to find a way to make every role partner satisfied".

\section{Review of Literature}

Various investigators recognized Gibb's findings a significant factor in the understanding supportive and defensive communication climate (Jablin 1995; Schnake et al., 1990; Proctor \& Wilcox, 1993; Moss, 1999; Kassing, 2008; Adler et al., 2009; Devito, 2008; Forward et al., 2011; McCornack, 2009; Hajdasz, 2012; Saba et al., 2012, Czech \& Forward, 2013; Alqahtani \& Saba, 2013; Kahtani \& Allam, 2013).

Weihrich and Koontz (1993) conducted a study and emphasized that in the process of operating an organization, communication is responsible for linking people to achieve common goals. Cheney (1995) emphasized in relation to democratic workplace and focused communicative link between participative decision making, openness, trust and supportiveness. Anene (2006) focused that the success of any organization not depends only on qualified personnel but also on the interaction between the personnel and clientele. Burleson (2009) explains the concept of supportiveness through outcomes of supportive interactions and defined as "verbal and nonverbal behavior produced with the intention of providing assistance to others perceived as needing that aid".

Forward, Czech and Lee (2011) conducted a study to investigate utility of Gibb's (1961) theory of defensive and supportive communication with the help of Costigan and Schmeidler in (1984) in their inspection tool. The results summarized with certain recommendations for interpreting and reconceptualizing the communication climate construct and emphasized that one defensive and supportive action highlighted on task and another supportive and defensive action emphasized on interpersonal relationships.

Hajdasz (2012) identified the Gibb's model of supportive and defensive communication climate and results focused on factors that affect the feelings of communication climate. Further researcher focused that supportive and defensive communication leads to positive and negative communication but negative influence of defensive communication overrides the positive impact of supportive communication on the on the rise communication climate.

Kahtani and Allam (2013) initiated a study among subordinate staff and their findings identified significant relationship between neutrality and other facets of defensive communication climate and correlation between provisionalism, empathy and spontaneity of supportive communication were found

Numerous researchers have been identified the relationships between role ambiguity and role conflict and worker attitude and behavior, incentive structures and rules, social pressures, job dissatisfaction, organizational commitment (Rizzo et al., 1970; Johnson \& Graen, 1973; Kahn et al., 1964; Greene \& Organ, 1973; Lyons, 1971; Tosi, 1971; Morris et al., 1979; Behrman, et al., 1984; Zahra, 1984; Ismail, 1990; Thomas, 2010; Zakari, 2011; Quarat-ul-ain, 2013). Singh et al., (1994) observed that role conflict can be seen in all Organizations. Jex \& 
Bliese (1999) has been said that many scholars pointed out role conflict treat same as the probable of work stressors.

Jehn (1997) pointed that individual worked in organizations force to be in conflict, whether knowingly or unknowingly and the influence of conflict is inescapable which can be seen either positive or negative. Robbins and Coulter (2003) suggested that when an individual is confronted by divergent roles faces the feelings of role conflict. Wu and Norman (2006) explored negative relationship between role ambiguity \& role conflict and job satisfaction.Lynch (2007) has observed that role conflict occurs when an individual have different expectations at the same time which made them to perform the divergence role. A research initiated by Schaufeli et al. (2009) observed that role conflict is found to be a moderator between job demands \& work holism and well-being \& job burnout.

Zakari (2011) initiated a study among nursing faculty in Saudi Arabia and highlighted that role conflict was found to be correlated with all the facets of commitment while role ambiguity was seen negatively related to normative and continuance commitment. Judeh (2011) conducted a study to identify the mediating effect of role conflict and role ambiguity on the relationship between organization commitment and employee socialization among telecom communication employees in Jordan. The result of the study revealed that role conflict and role ambiguity has emerged as significant mediators of the relationship between organization commitment and employee socialization.

Celik (2013) has observed that the partial and full mediation of depersonalization and emotional exhaustion consequences from the result of role conflict on the job performance of an individual. Most recently, Zhou, et al. (2014) conducted a study of middle level employees in Chinese local government with an aim to probe the relationship among role ambiguity, role conflict, job stress and role overload. Result of their study revealed that time pressure was found to be significantly related with role overload \& role conflict and job stress and job anxiety was observed positively and significantly related with role overload, role ambiguity and role conflict.

\section{The Goals of the Research}

In the present contemporary world the role conflict, defensive and supportive communication among subordinate is the major concern for the academicians and researchers. On the globe, it is evident that such variables have not been taken into consideration for investigations in a general and Kingdom of Saudi Arabia particularly. Therefore, the researchers initiated a study among subordinate staff working in various departments of Salman bin Abdulaziz University to understand their feelings related to emergence of role conflict, supportive and defensive communication climate. Hence, the following objectives were formulated:

- To explore the relationship and effect of role conflict on the facets of defensive communication climate among subordinate staff of Salman bin Abdulaziz University.

- To determine the predictors of role conflict on the defensive communication climate among subordinate staff.

- To find out the contribution and relationship of role conflict on the facets of supportive communication climate among subordinate staff of Salman bin Abdulaziz University.

- To explore the predictors of role conflict on supportive communication climate among subordinate staff of Salman bin Abdulaziz University.

In the light of the objectives of the present investigation and reviewed literature, the following null hypotheses were formulated and each hypothesis was verified to draw inferences. These hypotheses formulated were as follows:

HO1: There would not be significant relationship between role conflict and defensive communication climate and their facets among subordinate staff.

HO2: There would not be the predictors of role conflict within the facets of defensive communication climate.

HO3: There would not be significant relationship between role conflict and supportive communication climate and their facets among subordinate staff.

HO4: There would not be the predictors of role conflict within the facets of supportive communication climate among subordinate staff of Salman bin Abdulaziz University.

\section{Methods}

\subsection{Sample}

The study comprising of 368 subordinate staffs were selected randomly from different departments of Salman bin Abdulaziz University, Kingdom of Saudi Arabia. The sample break up can be seen in the following figure. 




Figure 1.

\subsection{Instrument}

1. The Communication Climate Inventory developed and standardised by Gibb (1961) was used in the study. The questionnaire consists of 36 items and each item has to be rated on a five point Likert style ranging from 1 strongly agree to 5 strongly disagree and divided 18 items into two categories of communication climate namely defensive (odd items) and supportive (even items) types of communication climate. Gibbs pointed out that the lowest possible overall climate scores is 18 and highest scores 90 on either the defensive or supportive .Further he said that communication climate inventory designed in such a manner that lower the score the greater extent to which either climate exists in the organization. However, low defensive scores probably is the indication that supportive scores are high and vice versa, the reason is very simple that both the climate would not exist at a same time in the organization and scores will vary according to subject being evaluated.

2. Role Conflict Scale measured by eight items adopted from a scale developed by Rizzo, House and Litzman (1970). The items of the scale has to be rated on 5 point rating scale ranging from $1=$ very false to $5=$ very true. The reliability of the instrument was found to be .82 .

3. Biographical Information Blank (BIB) The investigators prepared biographical information blank to gather in background information of the respondents such as age, gender, position, income, qualification, total work experience etc.

\subsection{Statistics Used}

Keeping the purposes of the present investigation in mind to verify the hypothesis Stepwise Multiple Regression Analysis was used. All the statistical analysis i.e. product- moment correlation and step wise multiple regression analysis were coded and analyzed by using Microsoft Excel and SPSS. 


\subsection{Procedure and Ethics}

The researchers were distributed 500 questionnaires among subordinate staffs at Salman Bin Abdulaziz University, Kingdom of Saudi Arabia and finally received 368; it means 74\% questionnaires were filled by the respondents. Initially, English version of questionnaire was translated into Arabic to make the respondents to understand each item in a effective manner with the help of experts to maintain the realm of the language. Clear instruction were given to these respondents and provided mobile numbers to them to call for help whenever they have doubts. The subjects were informed to take their own time to complete the questionnaires. The collected data put into statistical analyses for results. Further, it was necessary to maintain ethics of the research, certain formalities have been taken into account like permission has been taken from higher officials and assured to the respondents about the confidentiality will not revealed to any one at any circumstances and informed them that this study will be used for academic purpose.

\section{Results and Discussion}

Table 1. Mean, std. deviation and correlations matrix of defensive communication climate and their facets with role conflict among Subordinate Staff of Salman bin Abdulaziz University $(\mathrm{N}=368)$

\begin{tabular}{lcccccccccc}
\hline Variables & Mean & S.D. & 1 & 2 & 3 & 4 & 5 & 6 & 7 & 8 \\
\hline 1. Evaluation & 9.39 & 2.86 & - & & & & & & & \\
2. Control & 7.90 & 2.58 & $.406^{* *}$ & - & & & & & \\
3. Strategy & 8.18 & 2.66 & $.552^{* *}$ & $.419^{* *}$ & - & & & & \\
4. Neutrality & 9.01 & 2.55 & $.537^{* *}$ & $.266^{* *}$ & $.482^{* *}$ & - & & & \\
5. Superiority & 9.26 & 2.66 & $.583^{* *}$ & $.382^{* *}$ & $.498^{* *}$ & $.521^{* *}$ & - & & \\
6. Certainty & 9.27 & 3.21 & $.637^{* *}$ & $.404^{* *}$ & $.565^{* *}$ & $.560^{* *}$ & $.702^{* *}$ & - & \\
7. Total Defensive & 53.00 & 12.72 & $.814^{* *}$ & $.618^{* *}$ & $.763^{* *}$ & $.727^{* *}$ & $.805^{* *}$ & $.856^{* *}$ & & \\
Communication Climate & 53.90 & 6.62 & $.413^{* *}$ & $.217^{* *}$ & $.409^{* *}$ & $.351^{* *}$ & $.319^{* *}$ & $.412^{* *}$ & $.465^{* *}$ & - \\
8. Role Conflict & 21.90 & & & & & & & & &
\end{tabular}

** Significant at .01 level.

Table 1 shows the descriptive statistics (Mean and Standard deviation) and correlation between role conflict and all the facets of defensive communication climate. Result indicates that all the facets including overall defensive communication climate showed significant positive correlation with role conflict at $\mathrm{p}>.01$ level. Therefore, the proposed null hypothesis $\mathrm{H}_{1}$ was not accepted.

Table 2. Model summary of Stepwise Multiple regression analysis for defensive communication climate and their facets with role conflict among Subordinate Staff of Salman bin Abdulaziz University ( $N=368)$

\begin{tabular}{lccccc}
\hline Predictors & $\mathrm{R}$ & $\mathrm{R}^{2}$ & $\begin{array}{c}\text { Adjust } \\
\mathrm{R}^{2}\end{array}$ & $\begin{array}{c}\mathrm{R}^{2} \\
\text { Change }\end{array}$ & F Change \\
\hline Total Defensive Communication Climate & .465 & .216 & .214 & .216 & $100.702^{* *}$ \\
Total Defensive Communication Climate, Superiority & .473 & .224 & .220 & .008 & $3.962^{* *}$ \\
Total Defensive Communication Climate, Superiority, & .487 & .237 & .231 & .013 & $6.344^{* *}$ \\
Control & & & &
\end{tabular}

** Significant at .01 level.

a. Predictors: (Constant), Total Defensive Communication Climate

b. Predictors: (Constant), Total Defensive Communication Climate, Superiority

c. Predictors: (Constant), Total Defensive Communication Climate, Superiority, Control

d. Dependents variable: Role Conflict

It is evident from Table 2, that in the first step, defensive communication climate emerged as the most dominant predictor of role conflict among subordinate staff. The correlation coefficient between defensive communication climate and role conflict $(\mathrm{R}=.465)$ depicted that role conflict of subordinate staff are influenced by this factor. The obtained value of $\mathrm{R}^{2}=.216$ which shows the proportion of variation in the dependent variable explained by the regression model. It accounted for $21.6 \%$ variation, the value of $F$-change is $(F=100.702, p>.01)$ in the role conflict of the juniors at Salman bin Abdulaziz University. 
In the second step superiority emerged as the important predictor of role conflict among subordinate staff. The coefficient of correlation between superiority and role conflict along with total defensive communication climate and role conflict $(\mathrm{R}=.473)$ found significant. The coefficient of determination $\left(R^{2}=.224\right)$ accounted for $22.4 \%$ variation in the role conflict, $\mathrm{F}$-change value is $(\mathrm{F}=3.962, \mathrm{p}$ at .01$)$. The $\mathrm{R}$ squared change (.008) accounted for $.8 \%$ variation of superiority along with role conflict.

In the third step control emerged as the dominant predictor along with total defensive communication Climate and Superiority with role conflict. The correlation coefficient between predictor and criterion variable $(\mathrm{R}=.487)$ shows linear relationship. The coefficient of determination $\left(R^{2}=.237\right)$ accounted for $23.7 \%$ variation along with total defensive communication climate and superiority, $\mathrm{F}$-change value is $(\mathrm{F}=6.344, \mathrm{p}>.01)$ for the role conflict. The R squared change (.013) accounted for $1.3 \%$ variation of control along with role conflict.

Table 3. ANOVA of Multiple Regression of defensive communication climate and their facets on Role Conflict for Subordinate Staff of Salman bin Abdulaziz University ( $\mathrm{N}=368)$

\begin{tabular}{|c|c|c|c|c|c|}
\hline Mode & & Sum of Square & $\mathrm{df}$ & Mean Square & $\mathrm{F}$ \\
\hline 1. & Regression & 3478.300 & 1 & 3478.300 & $100.702 * *$ \\
\hline & Residual & 12641.776 & 366 & 34.540 & \\
\hline & & 16120.076 & 367 & & \\
\hline 2. & Regression & 3614.035 & 2 & 1807.017 & $52.739 * *$ \\
\hline & Residual & 12506.041 & 365 & 34.263 & \\
\hline & & 16120.076 & 367 & & \\
\hline & Regression & 3828.266 & 3 & 1276.089 & $37.789 * *$ \\
\hline & Residual & 12291.810 & 364 & 33.769 & \\
\hline & & 16120.076 & 367 & & \\
\hline
\end{tabular}

** Significant at .01 level.

a. Predictors: (Constant), Total Defensive Communication Climate

b. Predictors: (Constant), Total Defensive Communication Climate, Superiority

c. Predictors: (Constant), Total Defensive Communication Climate, Superiority, Control

d. Dependents variable: Role Conflict

Result shown in the table- 3, that the calculated F-ratio for total defensive communication climate $(\mathrm{F}=100.702$, $\mathrm{p}>.01)$, superiority $(\mathrm{F}=52.739, \mathrm{p}>.01)$ and control $(\mathrm{F}=6.972, \mathrm{p}>.01)$ was found significant and contributed to the role conflict among subordinate staff. Hence, the proposed null hypothesis $\mathrm{H}_{2}$ was partially accepted.

Table 4. Mean, std. deviation and correlations matrix of supportive communication climate and their facets with role conflict among Subordinate Staff of Salman bin Abdulaziz University ( $\mathrm{N}=368$ )

\begin{tabular}{lccccccccc}
\hline Variables & Mean & S.D. & 1 & 2 & 3 & 4 & 5 & 6 & 7 \\
\hline 1. Provisionalism & 6.83 & 2.78 & - & & & & & & \\
2. Empathy & 6.90 & 2.76 & $.685^{* *}$ & & & & & \\
3. Equality & 6.67 & 2.43 & $.612^{* *}$ & $.715^{* *}$ & - & & & \\
4. Spontaneity & 6.52 & 2.43 & $.523^{* *}$ & $.581^{* *}$ & $.606^{* *}$ & - & & \\
5. Problem orientation & 7.24 & 2.20 & $.531^{* *}$ & $.514^{* *}$ & $.503^{* *}$ & $.632^{* *}$ & - & & \\
6. Description & 7.79 & 2.14 & $.228^{* *}$ & $.283^{* *}$ & $.322^{* *}$ & $.270^{* *}$ & $.503^{* *}$ & - & \\
7. Total Supportive & 41.94 & 11.37 & $.800^{* *}$ & $.841^{* *}$ & $.826^{* *}$ & $.787^{* *}$ & $.787^{* *}$ & $.538^{* *}$ & - \\
Communication Climate & 4.94 & & & & & & &
\end{tabular}

**. Correlation is significant at the 0.01 level (2-tailed).

Table 4 depicts the descriptive statistics (Mean and Standard deviation) and correlation between role conflict and all the facets of supportive communication climate among subordinate staff of Salman bin Abdulaziz University. Result indicates that all the facets including overall supportive communication climate showed significant positive correlation with role conflict at $\mathrm{p}>.01$ level. Thus, the proposed hypothesis $\mathrm{H}_{3}$ was statistically not accepted. 
Table 5. Model summary of Stepwise Multiple regression analysis for supportive communication climate and their facets with role conflict among Subordinate Staff of Salman bin Abdulaziz University ( $N=368$ )

\begin{tabular}{cccccc}
\hline Predictors & $\mathrm{R}$ & $\mathrm{R}^{2}$ & Adjust $\mathrm{R}^{2}$ & $\mathrm{R}^{2}$ Change & F Change \\
\hline a. Empathy & .270 & .073 & .071 & .073 & $28.84^{* *}$ \\
\hline
\end{tabular}

** Significant at .01 level.

a. Predictors: (Constant), Empathy; b. Dependents variable: Role Conflict

It is evident from Table 5, that only empathy emerged as the most dominant predictor of role conflict among subordinate staff. The correlation coefficient between empathy and role conflict $(\mathrm{R}=.270)$ depicted that role conflict of subordinate staff are influenced by this factor. The obtained value of $\mathrm{R}^{2}=.073$ which shows the proportion of variation in the dependent variable explained by the regression model. It accounted for $7.3 \%$ variation, the value of F-change is $(\mathrm{F}=28.84, \mathrm{p}>.01)$ in the role conflict among subordinate staff at Salman bin Abdulaziz University.

Table 6. ANOVA of Multiple Regression of supportive communication climate and their facets on Role Conflict for Subordinate Staff of Salman bin Abdulaziz University ( $\mathrm{N}=368)$

\begin{tabular}{|c|c|c|c|c|}
\hline Model & Sum of Square & $\mathrm{df}$ & Mean Square & $\mathrm{F}$ \\
\hline \multirow{3}{*}{$\begin{array}{c}\text { 4. Regression } \\
\text { Residual }\end{array}$} & 1177.444 & 1 & \multirow{3}{*}{$\begin{array}{c}1177.444 \\
40.827\end{array}$} & \multirow{3}{*}{$28.840 * *$} \\
\hline & 14942.633 & 366 & & \\
\hline & 16120.076 & 367 & & \\
\hline
\end{tabular}

** Significant at .01 level.

a. Predictors: (Constant), Empathy; b. Dependents variable: Role Conflict

It is evident from the table-6, that the obtained F-ratio for empathy $(\mathrm{F}=28.840, \mathrm{p}>.01)$ was found significant and contributed to the role conflict among subordinate staff. Hence, the proposed null hypothesis $\mathrm{HO}_{4} \mathrm{was}$ partially accepted as far as empathy is concerned.

It is evident from the above results that strong relationship exists between the facets of defensive and supportive communication climate with role conflict. However, superiority, control and total defensive communication climate emerged as the predictors of role conflict but in the case of supportive communication climate only empathy emerged as a predictor of role conflict. The above results confirms that role conflict is emerging among juniors due to unnecessary control, command, not providing clear information about the organizational strategy, lack of support by the seniors, unwanted responsibilities and lack of socialization process. Further, it can be said that seniors does not show respect, not understanding the ideas, opinion, views of juniors forced them to be in the role conflict. However, role conflict always leads to absenteeism, turnover, and lower productivity, producing poor quality of products, job dissatisfaction and negative organizational commitment feelings and lower performance (Onyemah, 2008; Wu \& Norman, 2006; Judeh, 2011). Apart from the above explanations that most prominent situation of role conflict is two or more role expectations contradicted at a time as a result of inadequate defensive and supportive communication climate.

\section{Concluding Remarks}

The researchers observation based on literature available that role conflict associated with the various variables such as organizational commitment, job involvement, job satisfaction, absenteeism, and turnover intention (Morris \& Sherman, 1981; Zahra, 1984; Ismail, 1990; Jamal \& Badawi, 1995; Reichers, 1983; Ashforth \& Saks, 1996; King et al., 2005; Bettencourt \& Brown 2003; Harris et al.). Researchers felt that adequate manpower, explicit rules and regulations, instructions, group cohesiveness, adequate resources are required to accomplish the assigned task without any resistance to minimize the role conflict. Moreover, on the basis of analysis defensive communication climate forces the subordinate staff at Salman bin Abdulaziz University that they are not able to present their ideas effectively to accomplish the task assigned by the superiors for inputs or feedback. Hence, it is suggested that superiors must consider the feelings and thoughts of others to reduce the role conflict. However, communication climate and role conflict were observed related with each other and management must pay attention to overcome the difficulties posed by juniors at workplace and superior must have open attitude towards the subordinate staff.

In harmony to the concluding remarks to avoid role conflict and established proper communication climate in the workplace, manager must modify goals, undertake structural changes, redefine relations between authority and 
responsibility and, if required, transform the entire organizational structure (Kiss, 2007).Finally; this research has an avenue for other investigators for future research to focus on relevant issues of population to verify the generalization of the investigation.

\section{References}

Adler, R., Rosenfeld, L., Proctor, R., \& Winder, C. (2009). Interplay: The process of interpersonal communication. Don Mills, Ontario: Oxford University Press.

Alqahtani, F. A., \& Saba, T. (2013). Impact of Social Networks on Customer Relation Management (CRM) in Prospectus of Business Environment. Journal of American Sciences, 9(7), 480-486.

Anene, M. (2006). Effectiveness of communication in administration. Abraka: Delta State University.

Ashforth, B. E., \& Saks, A. M. (1996). Socialization Tactics: Longitudinal Effects on Newcomer Adjustment. Academy of Management Journal, 39, 149-178. http://dx.doi.org/10.2307/256634

Behrman, D. H., William, D., \& Perreault, J. (1984). A Role Stress Model of the Performance and Satisfaction of Industrial Salespersons. Journal of Marketing, 48(Fall), 9-21. http://dx.doi.org/10.2307/1251506

Bettencourt, L. A., \& Brown, S. W. (2003). Role Stressors and Customer-Oriented Boundary-Spanning Behaviors in Service Organizations. Journal of the Academy of Marketing Science, 31, 394-408. http://dx.doi.org/10.1177/0092070303255636

Burleson, B. (2009). Understanding the outcomes of supportive communication: A dual- process approach. Journal of Social \& Personal Relationships, 26(1), 21-38. http://dx.doi.org/10.1177/0265407509105519

Celik, K. (2013). The effect of role ambiguity and role conflict on performance of vice principals: The mediating role of burnout. Eurasian Journal of Educational Research, 51, 195-214.

Cheney, C. (1995). Democracy in the workplace: Theory and practice from the perspective of communication. Journal of Applied Communication Research, 23, 167-200. http://dx.doi.org/10.1080/00909889509365424

Cooper, C. L., Dewe, P. J., \& O’Driscoll, M. P. (2001). Organizational stress: A Review and critique of theory, research, and applications. Thousand Oaks, California, Sage.

Costigan, J., \& Schmeidler, M. (1984). Exploring supportive and defensive communication climates. In J. W. Pfeiffer, \& L. D. Goodstein (Eds.), The 1984 annual: Developing human resources (pp. 112-118). San Diego: Pfeiffer.

Czech, K., \& Forward, G. L. (2013). Communication, Leadership, and Job Satisfaction: Perspectives on Supervisor-Subordinate Relationships. Studies in Media and Communication, 1(2), 1-24. http://dx.doi.org/10.11114/smc.v1i2.122

Devito, J. (2008). Interpersonal messages: Communication and relationship skills. Boston: Allyn \& Bacon.

Forward, G. L., Czech, K., \& Lee, C. M. (2011). Assessing Gibb's supportive and defensive communication climate: An examination of measurement and construct validity. Communication Research Reports, 28(1), 1-15. http://dx.doi.org/10.1080/08824096.2011.541360

Gibb, J. (1961). Defensive communication. Journal of Communication, 11, 141-148. http://dx.doi.org/10.1111/j. 1460-2466.1961.tb00344.x

Glissmeyer, M., Bishop, J. W., \& Fass, R. D. (1985). Role conflict, role ambiguity, and intention to quit the organization: The case of law enforcement Officers. Academic Management Journal, 40(1), 82-111.

Greene, C., \& Organ, D. (1973). An evaluation of causal models linking the received role with job satisfaction. Administrative Science, Quarterly, 18, 95-103. http://dx.doi.org/10.2307/2391931

Hajdasz, P. (2012). An exploratory study of the relationship between defensive and supportive talk, verbal aggressiveness and communication climate (Unpublished Thesis). University of Ottawa, Canada.

Harris, E. G., Artis, A. B., Walters, J. H., \& Licata, J. W. (2006). Role Stressors, Service Worker Job Resourcefulness and Job Outcomes: An Empirical Analysis. Journal of Business Research, 49, 407-415. http://dx.doi.org/10.1016/j.jbusres.2005.06.003

Ismail, Z. (1990). Antecedents and outcomes of organizational commitment: A quasi-experiment in a field setting (Ph.D. dissertation). Kent State University.

Jablin, F. M. (1979). Superior-subordinate communication: The state of the art. Psychological Bulletin, 86, 1201-1222. http://dx.doi.org/10.1037/0033-2909.86.6.1201 
Jamal, M., \& Badawi, J. (1995). Job Stress, type 'A' Behavior and Employees' wellbeing among Muslem Immigrants in North America: A Study in Workforce Diversity. International Journal of Commerce \& Management, 5(4), 6-23. http://dx.doi.org/10.1108/eb047318

Jehn, K. A. (1997). A Qualitative Analysis of Conflict Types and Dimensions in Organizational Groups. Administrative Science Quarterly, 42(3), 530-57. http://dx.doi.org/10.2307/2393737

Jex, S. M., \& Bliese, P. D. (1999). Efficacy beliefs as a moderator of the impact of work-related stressors: A multilevel study. Journal of applied psychology, 84, 349-361. http://dx.doi.org/10.1037/0021-9010.84.3.349

Johnson, T., \& Graen, G. (1973). Organizational assimilation and role rejection. Organizational Behavior and Human Performance, 10, 72-87. http://dx.doi.org/10.1016/0030-5073(73)90005-6

Jones, G. R. (2007). Organizational Theory, Design, and Change (5th ed.). Pearson Prentice Hall, Upper Saddle River, New Jersey.

Judeh, M. (2011). Role Ambiguity and Role Conflict as Mediators of the Relationship between Socialization and Organizational Commitment. International Business Research, 4(3), 171-181. http://dx.doi.org/10.5539/ ibr.v4n3p171

Kahn, R., Wolfe, D., Quinn, R., Snoek, J., \& Rosenthai, R. (1964). Organizational stress: Studies in role conflict and ambiguity. New York: Wiley.

Kahtani, N. S., \& Allam, Z. (2013). Supportive and Defensive Communication Climate among Subordinate Staff of Salman bin Abdulaziz University: An Empirical Assessment. Life Science Journal, 10(4), 502-509.

Kassing, J. W. (2008). Consider this: A comparison of factors contributing to employees' expressions of dissent. Communication Quarterly, 56(3), 342-355. http://dx.doi.org/10.1080/01463370802240825

Katz, D., \& Kahn, R. L. (1966). The social psychology of organizations. New York: John Wiley \& Sons.

King, R. C., Xia, W., Quick, J. C., \& Sethi, V. (2005). Socialization and Organizational Outcomes of Information Technology Professionals. Career Development International, 10(1), 26-51. http://dx.doi.org/10.1108/ 13620430510577619

Kiss, I. (2007). Ljudski faktor - najvažniji element organizacijske structure. Ekonomija/Economics, 13(2), 379-392.

Lesikar, R. V., Pettit, J. D., \& Darsey, N. S. (1999). Communication in business. London: Longman.

Lynch, K. D. (2007). Modeling role enactment: Linking role theory and social cognition. Journal for the Theory of Social Behaviour, 37(4), 379-399. http://dx.doi.org/10.1111/j.1468-5914.2007.00349.x

Lyons, T. (1971). Role clarity, need for clarity, satisfaction, tension, and withdrawal. Organizational Behavior and Human Performance, 6, 99-110. http://dx.doi.org/10.1016/0030-5073(71)90007-9

McCornack, S. (2009). Reflect and relate: An introduction to interpersonal communication. Boston, MA: Bedford/St. Martin's.

Morris, J. H., Steers, R. M., \& Koch, J. L. (1979). Influence of organization structure on role conflict and ambiguity for three occupational groupings. The Academy of Management Journal, 22(1), 58-71. http://dx.doi.org/10.2307/255478

Morris, J., \& Sherman, J. (1981). Generalizability of an organizational commitment model. Academy of Management Journal, 24, 512-526. http://dx.doi.org/10.2307/255572

Moss, D. (1999). Humanistic and transpersonal psychology: A historical and biographical sourcebook. Westport, CT: Greenwood Press.

Onyemah, V. (2008). Role Ambiguity, Role Conflict, and Performance: Empirical Evidence of an Inverted-U Relationship. Journal of Personal Selling \& Sales Management, 28(3), 299-313. http://dx.doi.org/10.2753/ PSS0885-3134280306

Proctor, R. F., \& Wilcox, J. R. (1993). An exploratory analysis of responses to owned messages in interpersonal communication. ETC: A Review of General Semantics, 50(2), 201-220.

Quarat-ul-ain, Khattak, M. A., \& Iqbal, N. (2013). Impact of Role Conflict on Job Satisfaction, Mediating Role of Job Stress in Private Banking Sector. Interdisciplinary Journal of Contemporary Research in Business, 4(12), 711-722.

Rahim, A. (2002). Toward theory of managing organizational conflict. The International Journal of Conflict 
Management, 13(3), 206-235. http://dx.doi.org/10.1108/eb022874

Reichers, A. (1983). Conflict and organizational commitment (Ph.D. dissertation). Michigan State University.

Richmond, V. P., McCroskey J. C., \& McCroskey L. L. (2005). Organizational Communication for Survival: Making Work, Work. Allyn and Bacon, Needham Heights MA.

Rizzo, J., House, R. J., \& Lirtzman, S. I. (1970). Role conflict and ambiguity in complex organizations. Administrative Science Quarterly, 15, 150-163. http://dx.doi.org/10.2307/2391486

Robbins, S. P., \& Coulter, M. (2003). Management (7th ed., p. 372). Prentice Hall, Upper Saddle River, New Jersey.

Saba, T., Al-Zaharani, S., \& Rehman, A. (2012). Expert System for Offline Clinical Guidelines and Treatment. Life Science Journal, 9(4), 2639-26.

Schaufeli, W. B., Bakker, A. B., van der Heijden, F. M. M. A., \& Prins, J. T. (2009). Workholism, burnout and well-being among junior doctors: The mediating role of role conflict. Work \& Stress, 23(2), 155-172. http://dx.doi.org/10.1080/02678370902834021

Schnake, M. E., Dumler, M. P., Cochran, D. S., \& Barnett, T. R. (1990). Effects of differences in supervisor and subordinate perceptions of supervisors communication practices. The Journal of Business Communication, 27(1), 37-50. http://dx.doi.org/10.1177/002194369002700104

Singh, J., Goolsby, J. R., \& Rhoads, G. K. (1994). Behavioral and psychological consequences of boundary spanning burnout for customer service representatives. Journal of Marketing Research, 16, 558-69. http://dx.doi.org/10.2307/3151883

Thomas, K. W. (2010). Organization and Management External Relations. Retrieved from http://www.hq.nasa.gov/office/pao/History/SP-483/ch8-4.htm

Tosi, H. (1971). Organization stress as a moderator of the relationship between influence and role response. Academy of Management Journal, 14, 7-22. http://dx.doi.org/10.2307/254707

Weihrich, H., \& Koontz, H. (1993). Menedžment. Zagreb: Mate.

Wu, L., \& Norman, I. J. (2006). An investigation of Job Satisfaction, Organizational Commitment and Role Conflict and Ambiguity in a Sample of Chinese Undergraduate Nursing Students. Nurse Education Today, 26(4), 304-314. http://dx.doi.org/10.1016/j.nedt.2005.10.011

Zahra, S. (1984). Antecedents and consequences of organizational commitment. Business and Economic Review, 15, 26-32.

Zakari, N. M. A. (2011). The Impact of Nurse Role Ambiguity and Role Conflict on Nursing Faculty Commitment in Saudi Arabia. Life Science Journal, 8(3), 179-186.

Zhou, Y., Zeng, W., Hu, Y., Xi, Y., \& Tan, L. (2014). The Relationship among Role Conflict, Role Ambiguity, Role Overload and Job Stress of Chinese Middle-Level Cadres. Chinese Studies, 3, 8-11. http://dx.doi.org/10.4236/chnstd.2014.31003

\section{Copyrights}

Copyright for this article is retained by the author(s), with first publication rights granted to the journal.

This is an open-access article distributed under the terms and conditions of the Creative Commons Attribution license (http://creativecommons.org/licenses/by/3.0/). 